\title{
Fatigue resistance of AlSi11 alloy plastically wedged of chips
}

\author{
Odporność zmęczeniowa stopu AISi11 \\ konsolidowanego plastycznie z wiórów
}

\author{
ŁUKASZ WZOREK \\ MATEUSZ WĘDRYCHOWICZ \\ TOMASZ SKRZEKUT \\ PIOTR NOGA \\ MARCEL WIEWIÓRA \\ MATEUSZ PACEK *
}

DOI: https://doi.org/10.17814/mechanik.2017.11.181
Two extrudates made of AISi11 alloy have been produced in the co-extrusion process: solid billet and machining chips from the rolling process. The microstructure was observed, mechanical properties were determined on the basis of the 1axial stretch test, and the fatigue tests were performed to determine the fatigue resistance of the AISi11 alloy. KEYWORDS: AISi11, plastic consolidation, fatigue test

In Al-Si alloys, such as additives $\mathrm{Fe}, \mathrm{Mn}$ and $\mathrm{Sr}$ have a strong influence on the fatigue properties of these materials [1]. For example, the addition of iron significantly reduces fatigue resistance, because it creates $\beta$-15FeSi intermetallic compound. In addition, manganese improves fatigue strength, while strontium improves both impact strength and fatigue resistance [1].

High temperatures adversely affect the fatigue strength of metals and their alloys. In case of AISi12CuNiMg alloy, a marked decrease in resistance is visible after annealing at temperatures above $200^{\circ} \mathrm{C}$. This is due to the disappearance of the consolidation due to premature aging and the coalescence of the GuinierPreston (GP) zones during heating [2].

Similarly, Nicoletto et al. [3] investigated the effect of temperature on the fatigue resistance of eutectic Al-Si alloys. Test specimens cut from the motor pistons were subjected to fatigue tests at ambient temperature and at $250^{\circ} \mathrm{C}, 300^{\circ} \mathrm{C}$ and $350^{\circ} \mathrm{C}$. The increase in temperature in each case reduced the fatigue resistance [3].

In papers $[4,5]$, experiments concerning the influence of pore size on the fatigue strength of Al-Si alloy castings were described. Research has shown that cracks during the fatigue tests were the result of the presence of pores in the material that generated stresses in their surroundings, which is the main cause of fatigue failure $[4,5]$.

In turn, Maruna et al. [6] determined the fatigue

\footnotetext{
* Dr inż. Łukasz Wzorek (lukasz.wzorek@agh.edu.pl), mgr inż. Mateusz Wędrychowicz (mateusz.wedrychowicz@agh.edu.pl), dr inż. Tomasz Skrzekut (skrzekut@agh.edu.pl), mgr inż. Piotr Noga (pinoga@agh.edu.pl), mgr inż. Marcel Wiewióra (marcelw@agh.edu.pl), mgr inż. Mateusz Pacek (mateuszpacek21@interia.pl) - Wydział Metali Nieżelaznych AGH w Krakowie
}

strength of Al-Si-Cu-Mg alloy samples, on which Vshaped surface cuts with different rounding radii $(2 \mathrm{~mm}$, $1 \mathrm{~mm}, 0.3 \mathrm{~mm}$ and $0.1 \mathrm{~mm}$ ) were made. It was found that in the case of cuts with a radius of less than $0.3 \mathrm{~mm}$, the de-cohesion process initiated stress fields forming around the incisions, whereas in other cases, the low fatigue resistance was due to the presence of gas and shrinkage pores in the material [6].

\section{Methodology of own research}

The AISi11 alloy batch in the form of chips (fig. 1a) was prepared from the rolling ingot on a TUM 35 lathe without the use of a cooling agent. The chips were cold pressed under the pressure of $30 \mathrm{t}$ to form $10 \mathrm{~mm}$ high and $38 \mathrm{~mm}$ diameter samples (fig. $1 b$ ). a)

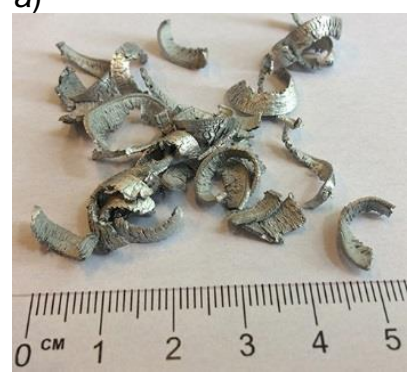

b)

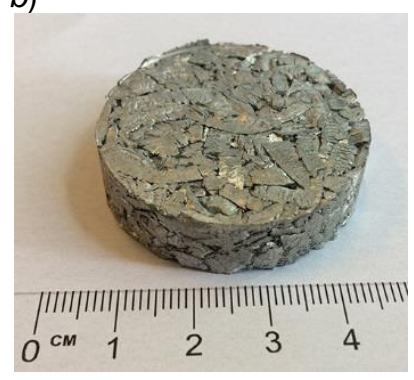

Fig. 1. AISi11 alloy batch material in the for of chips (a) and pressed sample (b)

The package of seven moldings was then pressed in a coincidence manner at $400^{\circ} \mathrm{C}$ with a processing rate of $\lambda$ $=25$ at an extrusion speed of $4 \mathrm{~mm} / \mathrm{s}$. For comparative purposes, a bar of solid ingot was also pressed. The bars produced were $8 \mathrm{~mm}$ in diameter.

A 1-axis stretch test at ambient temperature according to EN ISO 6892-1 was performed on a Zwick/Roell Z050 strength machine. Fatigue tests were carried out on the MTS 880 endurance machine. During the test, circular samples were subjected to cyclical loads, providing a 1axial tensile stress (sinusoidal, pulsating). The test was conducted at $10 \mathrm{~Hz}$ frequency and the maximum cycle 
stress of $140 \mathrm{MPa}$ (about $70 \%$ of the tensile strength). Hitachi SU-70 scanning electron microscope was used for the microstructure examinations.

\section{Test results}

Using the curve $\sigma=f(\varepsilon)$ (fig. 2), the material properties were determined, which are summarized in table I. The density of materials was measured using the Archimedes method.

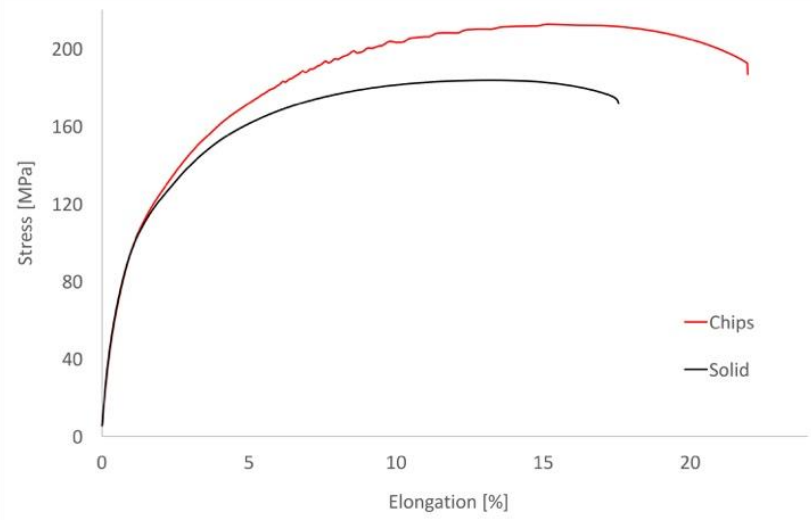

Fig. 2. Stretch curves of rod plastically consolidated from chips and solid material

TABLE I. Mechanical and physical properties of tested materials after extrusion

\begin{tabular}{|c|c|c|}
\hline Material & AlSi11 chips & AlSi11 solid \\
\hline Tensile strength $R_{\mathrm{m}}, \mathrm{MPa}$ & 210 & 184 \\
\hline Yield strength $R_{0,2}, \mathrm{MPa}$ & 84 & 84 \\
\hline Elongation $A, \%$ & 21 & 18 \\
\hline Density, $\mathrm{g} / \mathrm{cm}^{3}$ & 2.658 & 2.666 \\
\hline
\end{tabular}

\section{TABLE II. Results from fatigue tests}

\begin{tabular}{|c|c|c|c|}
\hline \multicolumn{2}{|c|}{ Solid material } & \multicolumn{2}{c|}{ Material from chips } \\
\hline $\begin{array}{c}\text { Number } \\
\text { of cycles }\end{array}$ & $\begin{array}{c}\text { Maximum force } \\
\text { recorded in sam- } \\
\text { ple, N }\end{array}$ & $\begin{array}{c}\text { Number of } \\
\text { cycles }\end{array}$ & $\begin{array}{c}\text { Maximum force } \\
\text { recorded in sam- } \\
\text { ple, N }\end{array}$ \\
\hline 20299 & 2808.51 & 21498 & 2808.13 \\
\hline 19135 & 2828.21 & 9480 & 2821.99 \\
\hline 6621 & 2817.92 & 8495 & 2731.42 \\
\hline 3978 & 2812.82 & 141 & 2640.60 \\
\hline 490 & 2770.53 & 115 & 2663.60 \\
\hline 420 & 2788.45 & 114 & 2637.41 \\
\hline 364 & 2784.35 & 108 & 2589.70 \\
\hline 192 & 2680,35 & 97 & 2580,74 \\
\hline 171 & 2751,37 & 85 & 2535,51 \\
\hline 163 & 2662,91 & 65 & 2458,34 \\
\hline
\end{tabular}

\begin{tabular}{|c|c|c|c|}
\hline 104 & 2540,79 & 60 & 2454,99 \\
\hline 58 & 2594,82 & 54 & 2443,76 \\
\hline
\end{tabular}

Table II presents results from fatigue tests (12 tests per each material). For chip-consolidated material as well as for solid material, the results are significantly scattered in terms of number of cycles (from over 50 to 20,000).

The microstructure of the breakthroughs for chipconsolidated material is shown after 108 cycles - in fig. 3 , after 9480 cycles - in fig. 4 . On the surface of the observed rods, silicon rich areas and iron phase separation can be observed.

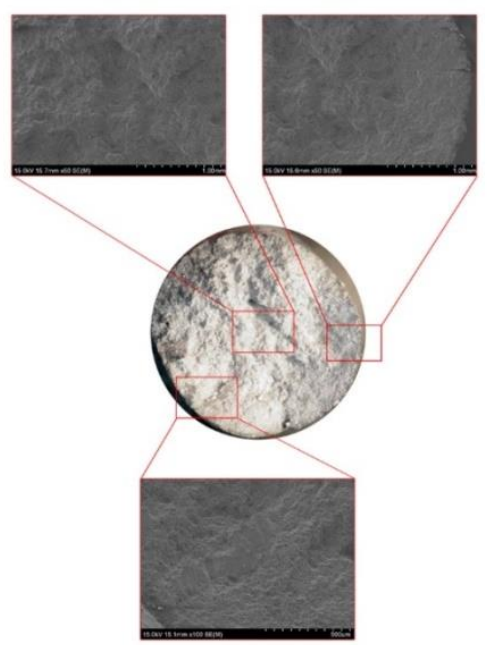

Fig. 3. Fatigue breakthrough of chip-consolidated samples after 108 cycles
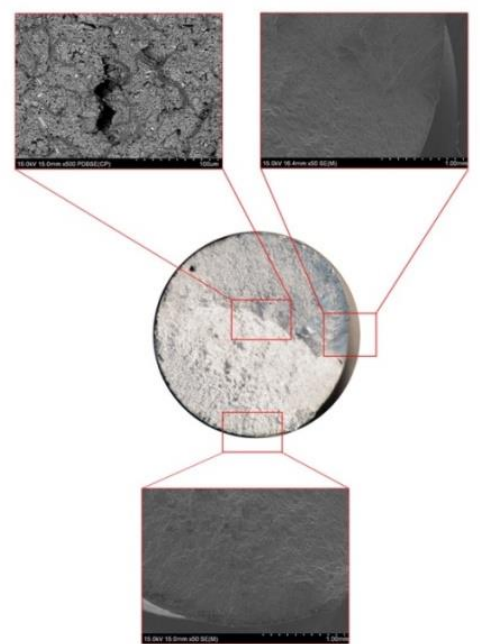

Fig. 4. Fatigue breakthrough of chip-consolidated samples after 9480 cycles

\section{Analysis of research results}

Consolidation of AISi11 alloys by cold pressing and extruding at elevated temperatures results in a rod with a density comparable to a rod extruded from solid material. Chip-extruded rods have better endurance properties. Significant increase in strength is due to the fragmentation of hard particles, including silicon, just at the cutting stage, leading to the strengthening of the material by creating larger number of barriers to 
dislocation [7]. In fatigue tests, the scattering of the number of cycles that cause de-cohesion can be observed - this applies to both types of rods. A large scatter of results is a derivative of pore, cracks, and inclusions presence, and confirmation of these conclusions can be found in the literature [4]. It should be emphasized that for samples, for which the number of cycles did not exceed 150, the measured maximum force did not reach the value set in the test program $(2750 \mathrm{~N})$. In the case of samples, for which de-cohesion occurs after a small number of cycles, the fatigue breakthrough is characterized by a strong irregularity of the surface and is similar to the breakthrough after the tensile test (fig. 3). A smooth, uniform area (fatigue zone) and a strongly uneven area with a considerable roughness (residual zone - fig. 4) can be distinguished on the surface of observed decays of decomposed samples after several thousand cycles. The fatigue zone is formed during the cyclic, reciprocal tensioning of adjacent surfaces, leading to their smoothing through crushing. Residual zone is caused by the rapid destruction of the sample at the final stage of the fatigue test. Between these zones, there is a transition zone, the morphology of which depends on the velocity of crack propagation.

\section{Conclusions}

- Better strength properties of the rod obtained from the chips result from the strengthening of the material due to the fragmentation of hard particles during the rolling stage.

- The presence of pores and inclusions reduces the resistance to cyclic loading in fatigue tests.

- The results of fatigue tests are characterized by high scattering, which should be explained by the disadvantages of the casting process and the feed preparation to extrusion process.

- Fatigue breakthroughs are characterized by the occurrence of different zones: fatigue and residual.

The work funded by statutory research under contract No. 11.11.180.653.

\section{REFERENCES}

1. Kosgey B.K., Maube S.E., Wangombe D.N., Maranga S.M., Kihiu J.M. "Effects of Additives on the Fatigue and Impact Properties of Recycled Al-Si Alloy Wheels". Jomo Kenyatta University of Agriculture and Technology (2011): pp. 1-4.

2. Konecna R., Nicoletto G., Kunz L., Svoboda M., Baca A. "Fatigue strength degradation of AISi12CuNiMg alloy due to high temperature exposure: a structural investigation". Procedia Engineering. 74 (2014): pp. 43-46.

3. Nicoletto G., Riva E., Di Filippo A. "High temperature fatigue behavior of eutectic Al-Si-alloys used for piston production". Procedia Engineering. 74 (2014): pp. 157-160.

4. Fintova S., Konstantova V., Konecna R., Nicoletto G. "Experimental study of porosity and fatigue behaviour of cast Al-S alloys". Department of Materials Science and Engineering (2008): pp. 1-8.

5. Ammar H.R., Samuel A.M., Samuel F.H. "Effect of casting imperections on the fatigue life of 319-F and A356-T6 Al-S casting alloys". Materials Science and Engineering. 473 (2008): pp. $65-75$.

6. Maruno Y., Miyahara H., Noguchi H., Ogi K. "Notch size effect in the fatigue characteristics of Al-Si-Cu-Mg cast alloy". Materials Transactions. 67 (2004): pp. 839-843.
7. Noga P., Wiewióra M., Wzorek A. „Wpływ obróbki cieplnej na własności stopu AISi11 konsolidowanego plastycznie z wiórów”. Mechanik. 7 (2017): pp. 621-623. 